\title{
A CRITICAL STUDY OF THE GENUS LEUCAS R. Br. (LAMIACEAE) FROM BANGLADESH
}

\author{
Mahbuba Khanam and Md. Abul Hassan $^{1}$ \\ Bangladesh National Herbarium, Chiriakhana Road, \\ Mirpur -1, Dhaka - 1216, Bangladesh \\ Key words: Leucas R. Br., Lamiaceae, Taxonomy, Bangladesh.
}

\begin{abstract}
Eight species of the genus Leucas R. Br. (Lamiaceae) have been recognized for Bangladesh after ciritical studies and described them in the paper with artificial key, illustrations and other necessary information.
\end{abstract}

\section{Introduction}

The genus Leucas R. Br. ( Lamiaceae), consisting of 80 species (Hedge 1990) with two main centres: one in Africa, especially eastern tropical Africa; the other in Asia, with its largest diversity in India with 43 species (Mukerjee 1940). The previous taxonomic accounts of Leucas for the present Bangladesh area have been given by Hooker (1885), Prain (1903) and Kanjilal et al. (1939) who reported only five species.

After thorough and critical studies of a large number of specimens from Bangladesh including the type specimens the authors have recognized the existence of eight species of the genus Leucas for Bangladesh, namely Leucas aspera, L. biflora, L. cephalotes, L. ciliata, L. indica, L. mollissima, $L$. vestita and $L$. zeylanica. Of these $L$. ciliata, $L$. mollissima and $L$. vestita are known only from greater Sylhet; and L. aspera, $L$. cephalotes, L. zeylanica are fairly common in most of the districts; whereas $L$. indica is by far the most common of all the species and L. biflora is very rare being recorded only from Chittagong. In the present paper, the taxonomic enumeration of the recognized taxa is presented in alphabetical order. Types and other specimens studied have been mentioned.

\section{Materials and Methods}

The description and illustrations have been prepared from the herbarium specimens preserved at DACB, CAL, K, E and DUH (Dhaka University Herbarium) as well as from freshly collected materials by the authors.

\footnotetext{
${ }^{1}$ Department of Botany, University of Dhaka, Dhaka-1000, Bangladesh.
} 


\section{Results and Discussion}

LEUCAS Burm. ex R. Br., Prodr.: 504 (1810)

Type species : L. flaccida R. Br.

Herbs or undershurbs, aromatic. Stem quadrangular, grooved, wooly, villous, pubescent or hirsute. Leaves opposite, elliptic-lanceolate to broadly ovate, entire to serrate, acute to acuminate. Inflorescence of dense axillary, less often terminal, usually distant whorls. Calyx 10- nerved, often striate, mouth equal or oblique, teeth 6-10, usually unequal, pubescent to hirsute. Corolla with upper lip erect, concave, villous externally, lower lip 3-fid, spreading, mid-lobe larger. Stamens 4, didynamous, ascending under upper lip, anthers connivent, cells divaricate, ultimately confluent. Disc entire or lobed, uniform or sometimes enlarged anteriorly, style shortly 2-lobed. Nutlets ovoid, triquetrous, obtuse to truncate-rounded at apex.

\section{Key to the species of Leucas:}

1. Whorls 2-4-flowered; stem procumbent

Whorls 6- many flowered; stem erect or ascending

2. Bracts linear, calyx mouth almost glabrous within

- $\quad$ Bracts lanceolate to elliptic, shortly awned, ciliate. Calyx mouth with a ring of hairs within

3. Bracts pubescent, without marginal bristles Bracts hirsute, with marginal bristles

4. Bracts forming a dense involucre, calyx mouth equal

- $\quad$ Bracts forming a loose involucre, calyx mouth oblique

5. Leaves pubescent on the upper surface, bracts ciliate

- $\quad$ Leaves and bracts villous

6. Calyx hairy outside and with a ring of hairs at mouth

- $\quad$ Calyx hairy above, glabrous below, mouth naked

7. Calyx villous outside and at the throat

- $\quad$ Calyx silky villous outside; pubescent at the throat biflora

2

3

cephalotes

indica

4

5

zeylanica

6

7

ciliata

aspera

vestita

mollissima

\section{Enumeration of the species}

1. L. aspera (Willd.) Link., Enum. Hort. Berol. 2 : 113 (1822). Hook. f., Fl. Brit. India, 4: 690 (1885); Prain, Bengal Pl.: 639(1903-reprint 1963); Mukerjee, Rec. Bot. Surv. India, 14 (1): 166 (1940); Keng, Gard. Bull. Singapore, 24: 101 (1969) and in van Steenis (ed.), Fl. Malesiana, 8(3): 337(1978); Phlomis aspera Willd., Enum. Hort. Berol. 2: 621 (1809). Bangla: Choto halkusa, Dulfi, Kusa, Shetodrone (PI. I. Fig. 1)

An erect or diffuse, annual herb, up to $50 \mathrm{~cm}$ tall, hirsute or scabrid. Leaves with 0.5 - 1 cm long petiole; lamina $4-8 \times 1-1.5 \mathrm{~cm}$, oblong-lanceolate often entire or slightly serrate, 


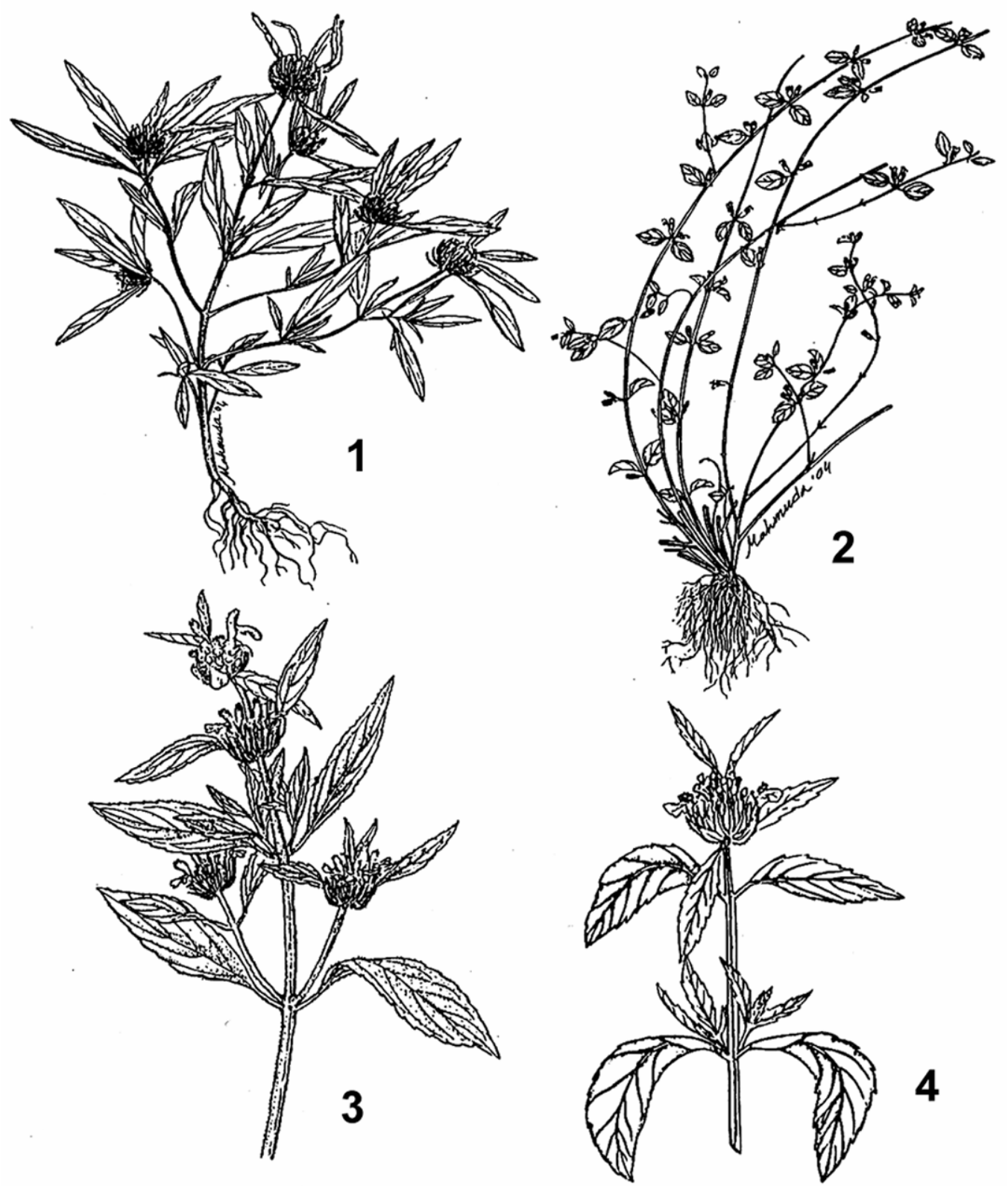

Plate - 1 (Figs. 1-4)

1. Leucas aspera (Willd.) Link., habit sketch (x 0.18). 2. L. biflora (Vahl.) Benth., habit sketch (x 0.18). 3. L. cephalotes ( Roth.) Spreng., habit sketch (x 0.18). 4. L. ciliata Wall ex Benth., habit sketch (x 0.18).

acute to obtuse. Inflorescence with terminal and axillary whorls. Bract c. $1 \mathrm{~cm}$ long, almost equaling the calyx, marginal bristles more than $0.5 \mathrm{~mm}$ long. Calyx c. $0.8 \mathrm{~cm}$ long, fruiting calyx c. $1.2 \mathrm{~cm}$ long, tubular, curved, constricted above the nutlets, usually smooth and 
glabrous below, ribbed and hirsute above, teeth triangular, spinulose, ciliate, the upper one longest. Nutlets c. $0.2 \times 0.1 \mathrm{~cm}$, obovoid-oblong, angular on inner surface, rounded on outer, smooth, brownish black. Fl.\& Fr.: Almost throughout the year, but especially during winter. 2n=22 (Fedorov 1969).

Specimens examined: Type: Caramania (B-WILLD, 10951-microfiche !) Bogra : Mohasthangar, 22 viii 1989, Mia, Rahman, Mahbuba \& Rezia M. 2191(DACB). Chittagong : Moheskhali, 31 viii 1981, Mia et al. M. 672 (DACB). Cox's Bazar : Cox's Bazar, 15 xii 1984, Khan, Huq \& Mia K. 6984 (DACB). Dhaka: Dhaka, Dhaka University, Shamsun Nahar Hall, 31 xii 73, M. Khanam 109(DUH). Gazipur : Chandra forest, 19 viii 1980, Huq, Mia, Mahbuba \& Momtaz H. 4643(DACB). Jessore: Jhikorgacha to Mallikpur, 2 ix 1983, Huq, Mia \& Mahbuba, H. 6166(DACB); Keshabpur, 30 viii 1983, Huq, Mia \& Mahbuba H. 5987(DACB). Rangamati : Pablakhali near Rangapahar, Khan et al. K. 4590(DACB). Tangail: Gorai, 5 viii 1976, Khan et al. K. 4158(DACB).

Economic importance: The juice of the leaves is used in psoriasis, chronic skin eruptions, in chronic rheumatism and applied to disperse painful swellings (Kirtikar and Basu 1918; Chopra et al. 1996). The flowers are being warmed with a little honey and given orally for coughs and colds to children (Caius 1998).

Ecology: Usually on sandy soil. Distribution: Throughout Indian sub-continent extending from Punjab to Assam and southward up to peninsular India.

2. L. biflora (Vahl.) Benth. in Wall., Pl. As. Rar.1: 62(1830). Hook. f.., Fl. Brit. India, 4: 683(1885); Mukerjee, Rec. Bot. Surv. India, 14(1): 180(1940); Cramer in Dassanayake \& Fosberg (eds.), Rev. Handb. Fl. Ceylon, 3:186(1981); Phlomis biflora Vahl., Symb. Bot. 3: 77(1794); R. Br. Prodr.: 504(1810); Prain, Bengal Pl.: 640(1903-reprint, 1963).

(Pl. I. Fig. 2)

A slender procumbent herb. Leaves with 0.4-1.0 cm long petiole. Lamina 1.5-5.0 x 0.5$2.0 \mathrm{~cm}$, elliptic to broadly ovate or oblong, coarsely serrate or crenate, truncate to rounded at the base, obtuse, hirsute on the upper surface, tomentose beneath. Inflorescence in axillary and terminal whorls, verticils lax, distant, 1-4-flowered. Bract c. $0.2 \mathrm{~cm}$ long, subulate, setaceous. Pedicel 0.2-0.3 cm long. Calyx 0.8-0.9 cm long, distinctly pedicelled, campanulate, 10-nerved, nerves prominent, hispid outside, sparsely hairy within except below the middle; teeth 10, narrowly lanceolate, ciliate, shorter than the tube. Nutlets 1.5 mm long, truncate at the apex, irregularly tuberculate, brown. Fl.\& Fr: January to July.

Specimens examined: Type: Habitat in India Orientali. Chittagong : Chittagong, Oct. 1940, S.K.Sen, N.L.Pal \& R.Khan (DUH); 2 vi 1967, N. Khan 2(K); near Gani Bakery, 24 iv 1985, M.Yusuf(K); Kotwali P.S., 4 i 1980, M.Yusuf 278(DACB).

Ecology: On dry soil. Distribution: India extending southward to Myanmar. 
3. L. cephalotes ( Roth.) Spreng., Syst. 2 :743(1825). Hook. f., Fl. Brit. India, 4, 689 (1885); Prain, Bengal Pl.: 639(1903-reprint, 1963); Kanjilal et al., Fl. Assam 3: 525 (1939); Mukerjee, Rec. Bot. Surv. India, 14 (1): 168 (1940); Press in Hara et al. (eds.), Enum. Fl. Pl. Nepal, 3 :156 (1982); Phlomis cephalotes Roth., Nov. Sp. : 262( 1821); Leucas capitata Desf., Mem. Mas. Par. 11: 8, t, 4 (1824). Bangla: Barahal-kusa

(Pl. I. Fig. 3)

Stout, erect, annual herb, up to $60 \mathrm{~cm}$ tall. Stem usually branched, grooved, scaberulous or hispidly pubescent. Leaves with 1.0 - $1.5 \mathrm{~cm}$ long petiole, pubescent; lamina $6.0-7.5 \mathrm{x}$ 1.5 - $2.0 \mathrm{~cm}$, ovate, serrate, subacute, pubescent on both surfaces. Inflorescence with whorls, usually terminal, globose, up to $4.0 \mathrm{~cm}$ in diam. Bract c. $1.4 \mathrm{~cm}$ long, elliptic- lanceolate, acute, shortly awned, ciliate, nerves prominent. Calyx enlarged in fruit, flowering calyx 1.0 $\mathrm{cm}$ and fruiting calyx $1.5 \mathrm{~cm}$ long, almost straight, slightly bent at the mouth, teeth 10 , pubescent without, with a ring of stiff hairs inside the mouth, as long as or longer than the teeth. Nutlets c. 0.3 x $0.1 \mathrm{~cm}$, ovoid, brown, smooth. Fl.\& Fr.: April to December.

Specimens examined: Type: "In India Orientali" Heyne (B?). Chittagong : Moheskhali, 5 iii 1978, A.Hassan 10 (DACB). Chuadanga : Kalabari, 2 i 1976, Huq et al. H. 1801(DACB). Dhaka : Shamsun Nahar Hall, 28 v 1973, M. Khanam 80 A(DUH); Neighbourhood of Biology Building, Curzon Hall, 12 vi 1942, A.K. Acharya (DUH); Jawgara, 3 xii 1968, S. Das 2 (DUH). Jessore : Magura , 5 i 1976, Huq et al. H. 1921(DACB); Rupganj, 29 viii 1983, Huq, Mia \& Mahbuba H. 5977(DACB); Keshabpur, 30 vii 1983, Huq, Mia \& Mahbuba H. 5995(DACB). .Kaliganj-Kotchandpur, 1 ix 1983, Huq, Mia \& Mahbuba H. 6104(DACB). Rajshahi : R. U.Campus, 19 i 1974 , Khan \& Huq K. 3832(DACB); Charghat, 24 x 1989, Mia, Rahman, Mahbuba \& Rezia. 2294(DACB).

This species may be easily confused with L. aspera in its dense floral whorls, but can be readily distinguished by its elliptic-lanceolate bracts and by the characteristic ring of hairs inside the calyx mouth.

Economic importance: The plant is officinal, being considered stimulant and diaphoretic. The seeds yield medicinal oil. The fresh juice is used specifically as an external application in scabies. The flowers are administered in the form of syrup as a domestic remedy for coughs and colds. The leaves are eaten as a pot-herb (Kirtikar and Basu, 1918 and Kanjilal et al. 1939; Chopra et al. 1996).

Ecology: On waste marshy places. Distribution: Throughout Indian subcontinent.

4. L. ciliata Wall ex Benth., Wall. Pl. As. Rar.1: 61(1830). Hook. f.., Fl. Brit. India, 4: 687(1885); Mukerjee, Rec. Bot. Surv. India, 14(1): 174(1940); Press in Hara et al. (eds), Enum. Fl. Pl. Nepal, 3: 156 (1982).

(Pl. I. Fig. 4)

A robust herb up to $100 \mathrm{~cm}$ tall. Leaves with $0.5-1.5 \mathrm{~cm}$ long petiole, lamina 4.0-8.0 $\mathrm{x}$ 1.0-2.5 cm, ovate or lanceolate, acute, coarsely serrate, base narrowed, hirsute with yellow appressed hairs, midrib and veins glabrous on the upper surface and densely hairy on the lower surface. Inflorescence in terminal and axillary whorls, globose, densely manyflowered. Bracts 1-1.1 x 0.1-0.2 cm long, linear with median one rib, margin ciliate, 
spinulose. Calyx 1.0-1.1 cm long, tubular, tube $0.7-0.8 \mathrm{~cm}$ long, straight, hairy outside and with a ring of hairs at the mouth; teeth $0.3-0.4 \mathrm{~cm}$ long, linear or lanceolate, ciliate, spinulose, stellately spreading in fruit. Nutlets $0.3-0.5 \mathrm{~cm}$ long, smooth, brown. Fl.\& Fr.: April to December.

Specimens examined: Type : Nepal, Wall. Cat. N. 2046 (CAL !). Sylhet : Sylhet, 26 viii 1821, Francis de Silva Wall. Cat. n.2046 (CAL).

Ecology: On waste marshy places. Distribution : Nepal, Bhutan, India and Myanmar.

5. L. indica ( L.) R. Br. ex Vatke in Oesterr. B. Zeits. 25 : 95 (1875). Press in Hara et al.(eds.) Enum. Fl. Pl. Nepal. 3 :156 (1982); Leonurus indicus L., Syst. ed. 10 : 1101 (1760); Leucas lavandulifolia Sm., in Rees. Cycl. : 20, n. 2 (1819); Mukerjee, Rec. Bot. Surv. India, 14 (1): 167 (1940); Keng, Gard. Bull. Singapore 24: 103 (1969); and in van Steenis (ed.), Fl. Malesiana, 8(3) : 338(1978) Phlomis linifolia Roth., Nov. Sp. : 260 (1821); Leucas linifolia (Roth.) Spreng., Syst. 2: 743 (1825). Hook. f., Fl. Brit. India, 4: 690 (1885); Prain, Bengal Pl.: 639(1903-reprint, 1963); Kanjilal et al. Fl. Assam 3: 524 (1939). Bangla: Dondocolos, Hal-Kusa, Sheto drone.

(Pl. 2. Fig. 5)

Erect or diffuse, aromatic annual, 16-60 cm long. Leaves with $0.5-1.0 \mathrm{~cm}$ long petiole; lamina 6.0-9.0 x 0.5 - $2.5 \mathrm{~cm}$, linear or narrowly oblong-lanceolate or elliptic-lanceolate, acute, base narrow, margin entire or obscurely crenate, more or less pubescent on both surfaces. Inflorescence whorls, terminal and axillary, often the whorls of the successive nodes joining to form a cylindrical spike . Bract c. $0.6 \mathrm{~cm}$ long, almost equalling the calyx, tip spinulose, pubescent. Calyx c. $0.8 \mathrm{~cm}$ long, tubular, curved, constricted above the nutlets, usually smooth and glabrous below, ribbed and scabrid above, mouth very oblique, produced on the upper side, teeth short, triangular, spinulose, the upper one longest, pubescent within only above the nutlets. Nutlets c. $0.3 \times 0.1 \mathrm{~cm}$, obovoid-oblong, angular on inner face, rounded on outer, smooth, brownish black. Fl.\& Fr: Almost throughout the year, but especially during winter. 2n=22 (Fedorov 1969).

Specimens examined: Type: LINN 726/28-microfiche !. Barguna : Barguna to Amtali, 19 iii 1989, Huq, Mahfuz, Rahman \& Mia H.9145(DACB). Bogra : Near A.H.College, 18 i 1974, Khan \& Huq K. 3795(DACB). Chittagong : Chittagong, 10 iv 1880, J. Wood (CAL); On the Bank of the Karnaphuli river, 19 iii 1899, A.T.Gage (CAL); Chittagong, Jan.-Feb. 1878, S. Kurz (CAL); Sandwip, Kalapani, 9 ii 1988, Mia \& Mahfuz M. 1485(DACB); Dinajpur: Singra forest, 12 x 1980, Huq, Rahman, Mia \& Mahbuba H.4739(DACB). Gazipur : Joydebpur; Bangladesh Rice Research Institute, 19 vi 1973, M. Khanam 86 B(DUH). Kushtia: Munshigunj to Alamdanga, 11 vi 1974, Khan \& Mia K. 3933(DACB). Rajshahi : Meghla, 2 iv 1974, M.Rahman 333(DACB). Sylhet : Sylhet, Francis de Silva Wall. Cat. No. 2048(K). 

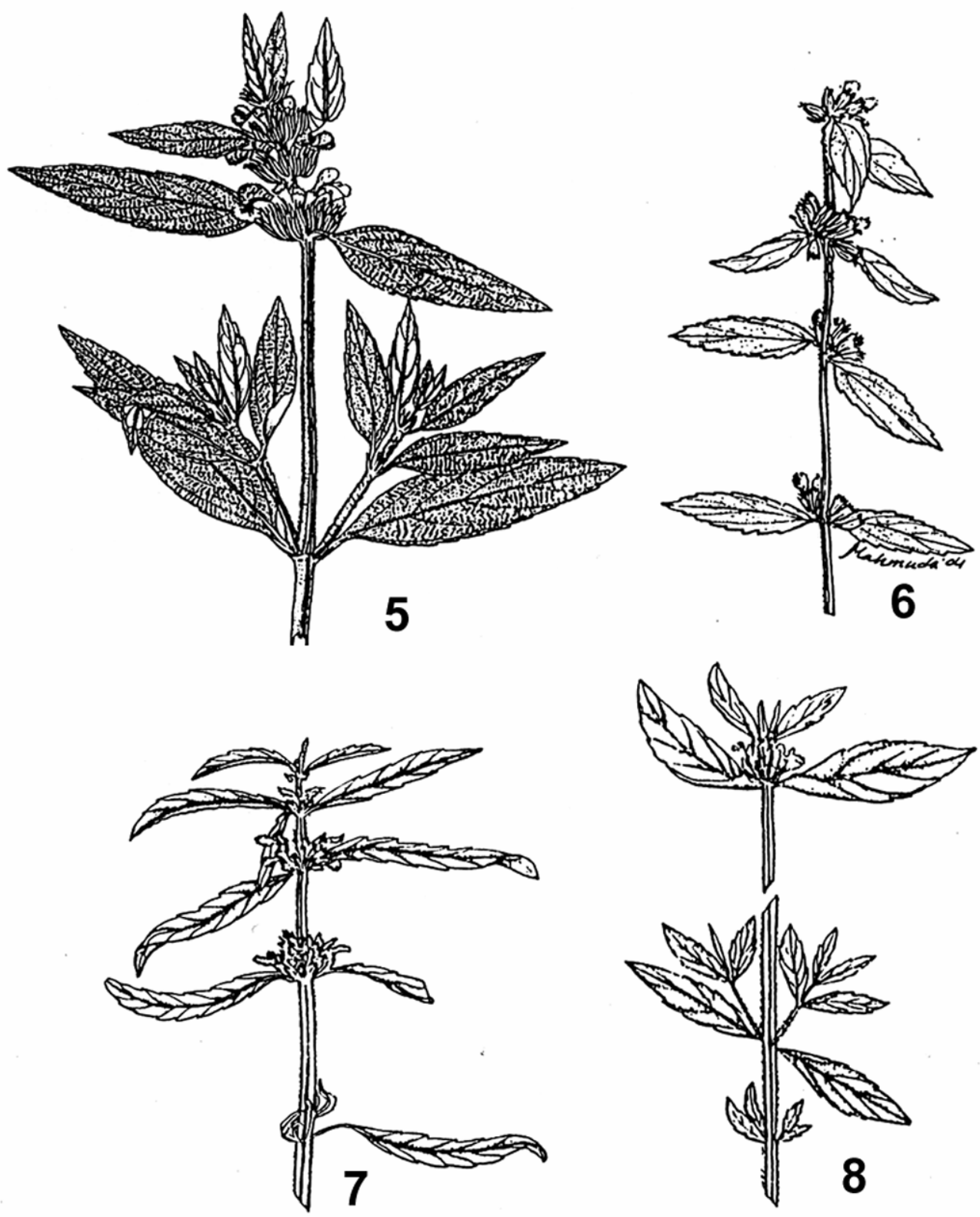

Plate - 2 (Figs. 5-8)

5. Leucas indica ( L.) R. Br. ex Vatke, Habit sketch ( $\times 0.18)$. 6. L. mollissima Wall ex Benth., habit sketch $(\times 0.18)$. 7. L. vestita Wall ex Benth., habit sketch $(\times 0.18)$. 8. L. zeylanica $(\mathrm{L}$. $)$ R. Br., habit sketch $(\times 0.18)$.

Economic importance : The plant contains isopunarane, rhamnoglycoside linifolioside (Ghani 2003). Leaves are roasted and eaten with salt for loss of appetite and in snakebite. Juice of leaves is employed in headaches (Chopra et al. 1996). 
Ecology : A common weed, on the cultivated lands but has been seen to grow in shady moist situations also. Distribution: Bangladesh, India and Myanmar.

6. L. mollissima Wall ex Benth., Wall. Pl. As. Rar. 1: 62(1830). Hook. f., Fl. Brit. India, 4: 682(1885); Prain, Bengal Pl.: 640(1903-reprint 1963); Mukerjee, Rec. Bot. Surv. India, 14(1): 183(1940); Cramer in Dassanayake \& Fosberg (eds.), Rev. Handb. Fl. Ceylon, 33:184(1981); Press in Hara et al.(eds.) Enum. Fl. Pl. Nepal, 3 :157 (1982).

(Pl. 2. Fig. 6)

Slender herbs with staggling branches. Stem hoary-tomentose with adpressed hairs. Leaves with c. $0.5 \mathrm{~cm}$ long petiole, densely hairy; lamina 3.0-5.0 x 1.0-2.0 cm, ovatelanceolate, serrate, acute, cuneate, strigosely villous above and tomentose below. Inflorescence in dense whorls, whorls many flowered. Bracts $0.3-0.4 \mathrm{~cm}$ long, linear, villous. Calyx 0.6-0.8 cm long, almost sessile, tube 10-ribbed, ribs softly villous outside, pubescent within on the upper part; teeth c. $0.5 \mathrm{~mm}$ long, subequal or alternately shorter, mouth equal. Nutlets $0.2 \times 0.1 \mathrm{~cm}$, obliquely truncate at the top, brown. Fl.\& Fr: January to July.

Specimen examined : Type : Nepalia, Wall. Cat. no 2054/1 (CAL!). Sylhet : Sylhet; Pandua, F. De Silva, Wall Cat no. 2054/2 ( K).

Ecology: On dry soil. Distribution : India, Sri Lanka, China and Malaysia.

7. L. vestita Wall ex Benth., Wall. Pl. As. Rar. 1 : 61(1830). Hook. f., Fl. Brit. India, 4: 687(1885); Mukerjee, Rec. Bot. Surv. India, 14(1): 175(1940).

(Pl. 2. Fig. 7)

A tall herb, tawny villous with spreading hairs. Leaves shortly petioled, hirsute. Lamina 5.0-9.0 x 2.5-4.0 cm long, ovate-lanceolate, acute, crenate serrate, narrowed to the base, villous on both surfaces with somewhat stiff hairs. Inflorescence terminal, whorls usually solitary, dense-flowered. Bracts c. $1.0 \mathrm{~cm}$ long, narrowly linear, densely ciliate with long, somewhat bristle-like hairs. Calyx about $1.0 \mathrm{~cm}$ long, tubular, straight, villous outside and at the throat, mouth not oblique; teeth short, slender, erect, sometimes spreading, ciliate with long hairs c. $0.1 \mathrm{~cm}$ long Corolla large, upper lip densely bearded with rufus-brown hairs. Nutlets c. $0.3 \mathrm{~cm}$ long, brown, smooth and shining. Fl.\& Fr: January to July.

Specimen examined: Type: Bangladesh, Sillet [Sylhet], Wall. Cat. n. 2039(CAL!). Sylhet : Sylhet, Francis de Silva Wall. Cat. n. 2039 (CAL).

Ecology : On dry soil in grassland. Distribution : India.

8. L. zeylanica (L.) R. Br. in W. T. Aiton, Hort. Kew. ed. 2(3): 409 (1811). Hook. f., Fl. Brit. India, 4: 689 (1885); Kanjilal et al., Fl. Assam 3: 525 (1939); Mukerjee, Rec. Bot. Surv. India, 14(1): 171(1940); Keng, Gard. Bull. Singore, 24: 101 (1969) and in van Steenis, Fl. Malesiana, 8(3) : 338(1978); Cramer in Dassanayake \& Fosberg(eds.), Rev. Handb. Fl. Ceylon, 33:183(1981); Phlomis zeylanica L., Sp. Pl.: 586(1753); L. involucrata Wall ex Benth., in Wall. Cat. n: 2047 nom nud; Prain, Bengal Pl.: 638 (1903reprint, 1963).

(Pl. 2. Fig. 8) 
An erect annual herb, upto $50 \mathrm{~cm}$ high. Leaves with 0.3-1.0 cm long petiole; lamina 4-8 x $0.5-2.5 \mathrm{~cm}$, broadly elliptic to elliptic-lanceolate, remotely serrate, acute, hirsute on dorsal surface and on the nerves beneath. Inflorescence of terminal whorls, rarely axillary. Bract c. $0.6 \mathrm{~cm}$ long, almost equalling the calyx, linear, hirsute forming a loose involucre, marginal bristles usually less than $0.5 \mathrm{~mm}$ long. Calyx c. $0.6 \mathrm{~cm}$ long, tubular, curved, glabrous below, ribbed and hirsute above, glabrous within, teeth triangular, spinulose, ciliate, the upper one longest. Nutlets c. $0.2 \times 0.1 \mathrm{~cm}$, obovoid-oblong, angular on inner surface, rounded on outer, smooth, brownish black. Fl.\& Fr: May to October.

Specimens examined:Type: India (LINN-740/14-microfiche !). Bandarban: Banbarban, 26 xi 1983, Khan et al. K. 6447(DACB); Comilla : Lalmai hills; Mainamati, 12 xi 1970, Khan \& Huq K. 2133(DACB). Dhaka: High Court compound, 30 v 1973, M. Khanam 82(DUH). Panchagarh : Panchagarh, 26 ii 1984, Mia et al. M. 1045(DACB). Sylhet: Jafflong road, 13 x 1973, Khan et al. K. 6447(DACB).

Economic importance : Juice of whole plant is used in scabies, skin-diseases, in headache and cold (Chopra et al. 1996). The juice of the leaves is sniffed of as a remedy for snakebite (Caius 1998).

Ecology: A weed of waste places. Distribution: Sri Lanka, India (Assam and Peninsula), extending eastward through Malaya Peninsula up to China.

\section{Acknowledgements}

The first author would like to thank the authorities of the Royal Botanic Gardens, Kew and Edinburgh for herbarium and library facilities during her visit to UK in 1991-92. Thanks are also due to the Overseas Development Authority and the British Council for the scholarship offered to her, and to Bangladesh National Herbarium for granting study leave. She also wishes to thank the authorities of the Central National Herbarium at Kolkata, India for herbarium and library facilities during her visit in 1999.

\section{References}

Caius, J.F. 1998. The medicinal and poisonous plants of India. Scientific Publishers, India.

Chopra, R.N., Nayar, S.L. and Chopra, I.C. 1996. Glossary of Indian Medicinal plants. National Institute of Science Communication, New Delhi, India.

Cramer, L.H., 1981. In Dassanyake and Fosberg (eds), Flora of Ceylon 3. A.A. Balkema. Rotterdam.

Ghani, A. 2003. Medicinal Plants of Bangladesh. Asiatic Soc. Bangladesh, Dhaka, $2^{\text {nd }}$ edn. pp. 603.

Fedorov, A.A. 1969. Chromosome numbers of flowering plants. Academy of Sciences of U.S.S.R., Moscow. pp. 926.

Hooker, J. D. 1885. Flora of British India, 4: 696-699 (Indian reprint 1973). Bishen Singh Mahendra Pal Singh, 23-A, Connaught Place, Dehra Dun, India. 
Hedge, I.C., 1990. In: Ali, S.I. and Nasir, Y. J. (eds.). Flora of Pakistan. Royal Botanic Garden, Edinburgh. Kanjilal, U.N., Das, S., Knajilal, P.C. and De, R.N., 1939. Flora of Assam. 3: 497-530, Calcutta.

Kirtikar, K. R. and Basu, B. D. 1918. Indian Medicinal Plants. 2 : 1010-1049, Indian Press, Calcutta.

Mukerjee, S.K., 1940. A revision of the Labiatae of the Indian Empire. Rec. Bot. Surv. Ind. 14(1);1- 205.

Prain, D. 1903. Bengal Plants 2: 859. (Indian reprint 1981). Bishen Singh Mahendra Pal Singh, 23-A, Connaught Place, Dehra Dun, India. 